\title{
ANCIENT EgyPtian TALES OF Travels
}

\section{By \\ Soliman, $\mathbf{R}$}

Assoc. Prof., Tourism Guidance dept.

, Faculty of Archaeology \& Tourism Guidance,

Misr Univ. for Science \& Technology

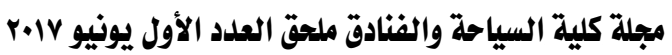

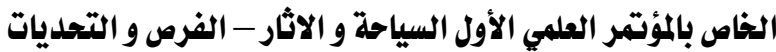




\section{AnCIENT EgYPTIAN TALES OF TrAVELS}

\section{English abstract}

Soliman, $R$.'

Travel was a crucial element of ancient Egyptian culture. Traveling activity attested for various professions, in the majority of cases, a journey was undertaken within the scope of the traveler's work and on behalf of the pharaoh. Ancient Egyptian literary stories provide information about voyages, expeditions, and encounters with other peoples and places. Some of these are tales of miraculous events when humans encounter supernatural powers, but others maybe partly based on accounts of real events. Therefore, literary sources provide both factual and fantastic descriptions of the foreign locations to which Egyptians traveled. The actuality privileged relationship between foreign travel and the production of literary fiction.

Keywords: Travel, voyages, literary stories.

\section{Arabic abstract}

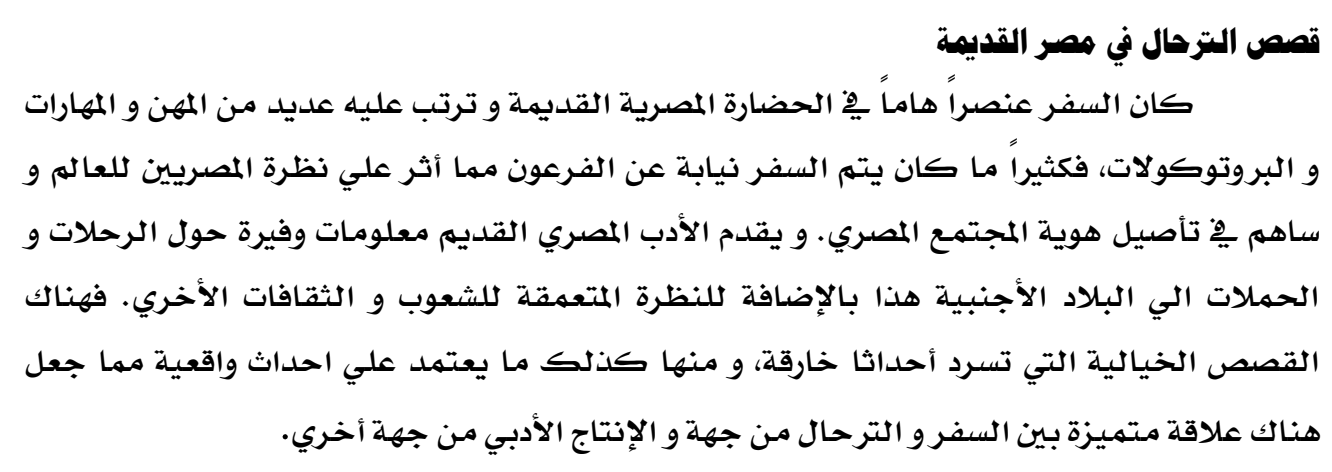


مجلة كلية السياحة والفنادق - ملحق العدد الأول يونيو Vا.r الخاص بالمؤتمر العلمي الأول

\section{Tales of Travels}

'What are these foolish journeys which they have had you make?'

Wenamun 2.22

\section{Introduction}

Ever since humanity was created on earth a system of recording was necessary to register things around according to his own perception. Thus, documentation was necessary and lead to written materials, however not all written documents are considered literary texts. The exact date of when literature has started remains unknown. A legacy of stories, dramas, myths, legends, songs, instructions and literary works were inherited helping the comprehension of their lineages' culture. Evidence of travel varied; nonfiction sources include formal documents, expeditions' texts, biographies, as well as, graffiti engraved by visitors. ${ }^{2}$ Some of these tales have imaginary events where humans encounter supernatural creatures and powers, thus offering both facts and peculiar descriptions of the destinations they traveled to. ${ }^{3}$

The Egyptians were certain their homeland was where the cosmos came into being, and that foreign lands were merely useful attachments offered by the gods for the purpose of helping maintain the world order within the only part of the world of any worth - Egypt. Travel in ancient Egypt was outside the person's usual span, away from his home and usual surroundings. The Egyptian stories reveal journeys into unfamiliar domains, going past the protagonist's habitual zone into unfriendly threats, causing him to look within and re-consider his own personality.

Travel implies to either long or distant expeditions but in reality it is a word describing a journey. Journeys overland reflected the ancient Egyptian beliefs of their path through life, whilst water journeys encompassed volatility and danger. Danger of the unknown boundaries was portrayed in the protagonist's rejection of the Egyptian culture and traditions. It was believed that life away from the Egyptian sociocultural territories would only lead to failure of evading the ideologies of ma'at or justice. ${ }^{4}$ The ancient Egyptians own willpower within order or within the ma'at code and the divine grace bestowed.

\section{Travel and Tourism}

There is a difference between travel and tourism; travel encompasses a vast amount of objectives including pleasure, business and immigration. Meanwhile, tourism is defined as a brief voyage to anonymous destinations 
away from the accustomed place, away from their hometowns. Noteworthy, all tourism includes travel, whilst not all travel is tourism. Even ancient Egypt had travel types or what we call nowadays, types of tourism; they are all self-motivated and vary a lot. ${ }^{5}$ Based on the UNWTO definition of tourism, it is categorized into Domestic Tourism that involves trips made by local residents within their own countries. An example of such is found in the tale of the Eloquent peasant who traveled from Wadi Natroun to Herakleopolis. Second, International Tourism involves trips between two countries, outbound tourism, such as in the report of WenAmun. Most vital is the return home to assure that the voyage was not for immigration. ${ }^{6}$ Evidence of several excursions ${ }^{7}$ were confirmed ever since the Early Dynastic period to Gebel Tjauti, ${ }^{8}$ King Hor Aha and Khasekhemwy to Nubia, ${ }^{9}$ King Djer to Gebel Sheikh Suleiman ${ }^{10}$ and many other missions were attested up until the Thirtieth Dynasty. ${ }^{11}$

\section{Motivation for travel}

The question is "Why do people travel? What motivates them?" It all depends on their incentive to travel whether for business, cultural, religious purposes, besides social abilities which unquestionably depended on the means of transportation. Throughout history there have been a range of motivations for going on a trip of ultimate drive was the search for food and supplies. Furthermore, their objectives for travelling were usually personal, political, military, administrative, as well as economic. Other motivations included enlarging settlement areas, logically trade and hopes of moneymaking along, curiosity, health reasons and the aspiration to expand one's scope of the foreign lands and cultures. Ancient Egyptian business travelers targeted trade, whilst cultural travelers searched more experience nourished by their inquisitiveness about unfamiliar lands, clearly a motive for the protagonist in the story of the Doomed prince.

Other repetitive travels were motivated by religious incentives, a mere desire to reach Abydos, and become stronger by accomplishing pilgrimage. ${ }^{12}$ However, at numerous times of the year a huge flood of celebrants assemble to celebrate a deity's jubilee. Herodotus states these popular festivities took place at Bubastis, Busiris, Sais, Heliopolis and Buto. ${ }^{13}$ Unalike the priests and the king conceivably, took a journey between the known and the unknown into the sacredness of the gods' paths, such as that of the Theban sacred space or simply the rituals taking place between the temples of the Theban nome ${ }^{.14}$ 


\section{Transportation means}

Transportation was an extremely substantial issue for travelling and for the development of travel destinations. No matter what motivates the traveler, he still needs to find the adequate mode of transportation. Ever since the Old Kingdom times, Egyptians travelled extensively by both land and water confirmed by the necessity to travel. The methods of transport differed according to the traveler's social status; either by foot or donkeys, which also helped in carrying the traveler's possessions. For overland transport, pack animals were used, as well as, vehicles. Other carrying methods were palanquins, which were used mainly by the elite of the Old and Middle Kingdom during short journeys. ${ }^{15}$ Chariots were attested since the Seventeenth Dynasty for warfare, hunting, sports but also for travel. ${ }^{16}$ The inappropriateness of chariots was restricted due to its delicate wheels and expensive maintenance of both the horses and chariot.

Several civilizations built watercrafts but it still remains undetermined as to who were the inventors; practically the Egyptians navigated the river Nile. It was an easy and rapid river that allowed sailing upstream along with the northern wind. Boats were used since the Fifth Millennium BCE; ${ }^{18}$ they were a vital part of Egyptian traffic system. A varied range of ships and boats were used for transporting cargo and passengers on inland waterways and at sea. Ever since the early dynastic times, the ruler sent his officials down the Nile, to the eastern desert, into Sinai and beyond frontiers to Sudan and the Levant.

\section{Accommodation facilities}

Accommodation was allocated in camps formed of semicircular irregular stone huts nearby the way from Gebel el-Asr to Tushka. ${ }^{19}$ Other alternatives included tents, such as those used during the Megiddo campaign. When kings travelled up or down the Nile, they used to stay in royal rest houses recognized as mooring-places of Pharaoh. The Wilbour papyrus mentions one of these spacious places to have reached the size of a hundred and ten hectares, such as the palace of Hardai. ${ }^{20}$ The king had these rest houses ready before his arrival with supplies to upkeep him, his chariotry, and even his harem. The overseer of these rest houses received letters including the list of supplies that were to be sent in preparation. An example was: Weni the Elder, a supervisor during the reign Pepi I had to manage the provisions for royal voyages: "I did so that his majesty praised me, when preparing court, when preparing the king's journey (or) when making stations. I did throughout 
so that his majesty praised me for it above everything."

\section{Professions of travellers}

Expeditions differed in size and in the profession of their members; ${ }^{21}$ expedition records unluckily often mention only the higher rank members. As an example, architects on behalf of the pharaoh traveled for professional purposes to oversee official construction tasks. Numerous times Pepy I sent expeditions to Qus to oversee the digging of a canal, as well as the royal building projects in Heliopolis 22

Travelers of different professions regularly travelled, such as traders, couriers, and army members. Nevertheless, other professions were often but not entirely traveling as members of expeditions included physicians, architects, scribes, craftsmen, laborers, hunters, fowlers, brewers, sandal makers, bakers, scribes, millers, servants and priests. ${ }^{23}$

Foreign merchants visited the Nile Valley, such as the Asiatics in the scenes found in the Middle Kingdom tomb of Khnumhotep at Beni Hassan. These merchants were labeled by the Egyptians as official foreign representatives that came to offer tribute and not as merchants who came in search for revenues. Since ancient Egypt was known to be an agricultural state and particularly cereal based harvests were distinguished; the haulage of such cargos was common during the Middle Kingdom to both granaries and within expeditions.

Scribes traveled by official command to new places of service as necessary. Besides, also traveling for pleasure existed to cultivate the traveller's curiosity regarding the magnificent structures of their ancestors. They recorded their visits to these sites, such as a whole school of scribes documenting their visit to Djoser's pyramid complex. Simple recurring inscriptions assured scribes traveling since the beginning of their careers. They did not chisel their names but rapidly scratched or painted their names as evidence to have visited these sites. ${ }^{24}$

Craftsmen traveled along expeditions and royal building projects. ${ }^{25}$ Mobility was hence clearly impartial of social or financial background and not a status symbol. In the New Kingdom, the king traveled yearly to Thebes for obligatory religious reasons to celebrate the Opet Festival. ${ }^{26}$ As for the priests they travelled to accomplish particular requirements or arrange religious ceremonies at temples. In addition, military campaigns were further verified in the annals of Tuthmosis III. 
Travel had a significant impact on the Egyptians individuality in society and developed their broad view. Obviously, the protagonist's occupation was a major reason for travelling as most were on behalf of the pharaoh. For instance travelling to Nubia and the eastern desert occurred since the times of Snefru and Weni the elder. Some travelled to settle government issues, or even to redeem justice like in the story of the Eloquent peasant. Others travelled to make a living by selling their additional harvests in markets, or by working on temples and pyramids. During civil wars commoners were enlisted within their hometowns, while militants remained based at the borders to halt any foreign invasion.

\section{Private journeys and famous adventurers}

Records of private journeys are uncommon; but they surely occurred for personal reasons, such as marriage. One of the few known pieces of evidence for private travelers (other than those attested in Egyptian literature) was perhaps Heqanakht of the Eleventh Dynasty, who owned land near elLisht but sent letters to his family in Thebes. His motive for traveling was unknown whether it was for governmental purposes or for private reasons. ${ }^{27}$

Of the most famous travelers of ancient Egypt Weni and Harkhuf, whom both date back to the late Sixth Dynasty their adventures as leaders were registered as autobiographies in their tombs. Nubia was one of the locations they travelled to but it remains yet debatable as to where were the other regions these men had been sent to. They returned to Egypt with an assortment of merchandises, such as animals and gold.

It was believed that Harkhuf's official business trip lasted either seven or eight months time returning with exceptional gifts. His expeditions targeted the latest exotic trade resources extending up to unknown southern lands of Yam, Irtjet and Wawat. A characteristic tourist's behavior involved returning home with souvenirs, which Harkhuf obtained a dancing dwarf as a gift for his young king who ordered the expedition's return at once and to provide distinct care to the dwarf. ${ }^{28}$

\section{Travel experiences}

Travel had essential effects on the Egyptian society, a crucial role in both ideas' exchange and innovations, the traveler's experience increased and expanded his perspectives by interacting with foreigners either at foreign lands or Egyptian grounds. In the Tale of Sinuhe the feeling of foreignness aroused his passion for Egypt mentioning, "It was like the nature of a dream, 
like a Delta man seeing himself in Elephantine, a man of the marshy lagoons in southern Egypt". 29

An ample afterlife was granted to the ancient Egyptians hoping they would be buried within their homeland. Thus, to die and be buried abroad meant they would be denied of that lavish afterlife. ${ }^{30}$ Distinctly conveyed in the story of the Shipwrecked Sailor: "Then, a ship shall come from the Residence with sailors that you (would) recognize. You shall leave with them to the Residence; you shall die in your city." protagonist mentions: "What could be more important than that my body be buried in the land where I was born?"32

Much later, during the reign of King Smendes, in the Twenty-first Dynasty, the report of Wenamun, a thorough narrative account of a personal journey full of mishaps; ${ }^{33}$ documented only once on a papyrus manuscript now in Moscow. An administrative report explaining an official's expedition to modern Syria to fetch cedar wood for god Amun's boat during an era in which Egypt had lost its supremacy. Wenamun faces many misfortunes of theft by pirates or his shipmates and mistreatment by the prince of Byblos. But ultimately was protected during his return by the local queen of Cyprus and regrettably the end of the story remains unpreserved.

The Old Kingdom texts picture travel as an issue of either economical or political apprehension. The travelers or heroes of these texts never feared to travel across borders to unfamiliar foreign places. ${ }^{34}$ The idea of travel was to assure the fact of the traveler's exceptional accomplishments, which is presented in the text of Harkhuf's expedition. ${ }^{35}$

Unfamiliar domains were visited with mixed feelings of curiosity; besides greed and fear which all existed within the defenseless Sinuhe. In this story, the protagonist faced risks and dangers crossing the river in a rudderless raft, in which he could have easily been swept; "At the dinner hour, I had reached the town of Negau. I crossed the river on a rudderless raft, with the wind from the West". Besides he had lived a tiresome life in exile: "tarried there in the open fields" to an extent that a man "he showed dismay of me and feared". ${ }^{36} \mathrm{He}$ was allowed to return to his birthplace only by the sustenance of God's forgiveness and authority. ${ }^{37}$ Similarly, in the Shipwrecked Sailor a feeling of danger, chaos, and injustice and to the extent of the taste of death causes the protagonist and his crew to reach the "last corners of Nubia", past the Nile cataract. Thus, a clear distinction of overcoming threats by reaching the borders of Egypt. ${ }^{38}$ 
Although later, an example of the vigorous horrors Wenamun challenged include his sea voyages "Do not come to look for danger in the sea. If you look for danger in the sea, look also at me" and "If the sea carries (me) and the wind pushes me towards the land where you are, will you allow that I am received to be killed, I being a commissioner of Amun?"39 Thus, such report revealed the prominence and safety of the Egyptian maritime in the Mediterranean Sea. ${ }^{40}$ It was an exceptional fictional narrative of that era; uneasy to classify it, made it more significant and especially that most Egyptian fiction is usually predating its time of composition. Only a single version of the report, and no other administrative documents mentioned it. Most scholars oppose as to whether the story is fictional or was it real. In other words its historicity remains so far unsettled.

\section{Travel destinations}

Some Middle Kingdom protagonists' journeys travelled south, such as the Eloquent Peasant traveling from Wadi Natrun to Herakleopolis, passing the Nile close by Memphis, meaning at the very juncture between Upper and Lower Egypt. ${ }^{41}$ Moreover, returning from Libya, Sinuhe turns southward but avoids the central threatening "Residence", ${ }^{42}$ roughly the same location as the Eloquent Peasant; then he resumes his flight along the edge of the Delta, passes the "Walls of the Ruler" or the residence; walls which were built to prevent the Asiatic, and ultimately reaches an afar location, Asia.

\section{The land of Punt}

No matter where or when, travel will always remain fundamental for any economy. Egyptian exploratory expeditions to Punt, Byblos, the eastern desert and Nubia were driven by economical motives to exchange luxurious products. Several Egyptian rulers sent expeditions to the land of Punt; a land's location remains yet anonymous. Based on the Egyptian descriptions Punt was a tropical region, with palms and apes, which could be reached both by an overland route and from the Red Sea coast. Egyptian sources locate Punt southeast from Egypt, near Wawat and Kush (upper and lower Nubia). Egyptians had traded with Punt ever since the Old Kingdom times. Newer research tends to locate Punt near Eritrea, Ethiopia and Sudan, between the Blue Nile and the Red Sea. Punt exported many luscious commodities of which elephant tusks, spices, cosmetics, gold, ebony, animal skins, incense, frankincense, and myrrh trees. Remains of these trees luckily continue to have their roots detectable in front of the temple of queen Hatshepsut at Deir el Bahari. 
The most popular expedition to Punt dates back to the reign of the Eighteenth Dynasty queen Hatshepsut decorated on the walls of her temple at Deir el Bahari. Significantly Hatshepsut's expedition to Punt features her vital royal, sacred and ideological commitment to reestablish Egypt's splendor after the Second Intermediate Period, by recurring the Old and Middle Kingdoms accomplishments, thus strengthening her own authority. ${ }^{43}$

Significant to mention, many other evidential scenes of Punt are found all around Egypt; in the tomb of Rekhmire, in the mortuary temple of Amenhotep III at Kom el Heitan, even Karnak temples has Horemheb and Sety I mention Punt, in the temple of Ramses II at Abydos and finally in the Papyrus Harris of Ramses III. Nevertheless, the late Ramesside era has way little evidence of the land of Punt, possibly because the maritime forces were sent north to protect the borders. Egyptian trading expeditions in the Red Sea relied upon the presence of their armed maritime forces to ensure that the people of Punt did not oppose their landings on the Horn of Africa and to guarantee that the terms of trade were favourable to the Egyptians. ${ }^{44}$

Ancient Egyptian literature enhanced the belief that Punt was a semimythical land to the Egyptians; recognized as "Ta Netjer," the land of the gods, a charming land from which all-virtuous things came. It was through the wide spread tale of the Shipwrecked sailor that the exalted land of Punt became more distinguished. In the tale, the protagonist sailor spoke to a gigantic serpent named "Lord of Punt", which in turn provided him with gold, precious animals, spices and facilitated the sailor's return home.

\section{Travel Literary outcomes}

Travel literature offers various intercultural environments and a large amount of sources demonstrate Egypt's traditional and royal methods of exchange with Near Eastern neighbours; a clear concise image of some distant societies, along with their administrative conditions. For example, the definite theorized evolutionary connection of both "The Shipwrecked Sailor and the tale of Sinuhe" are part of the autobiographical and instructional genres. Thus, to distinguish between literary contexts and historical or fictional literature becomes tentative. The Shipwrecked sailor was considered a short folk tale, circulated orally among common folks providing strange magical events in a non-elevated form of speech. Neither personal names were mentioned nor any characters developed. A fictional explorer's tale that presents the protagonist's route, undoubtedly an unreal tale in the narrative sense of the snake's characteristics. ${ }^{45}$ 
Inquisitiveness and the need to investigate and acquire from one's ancestors has been a crucial inspiration for ancient Egyptians to travel. They explored and esteemed their past's heritage. Adventures of traveling were merely provided by fiction, exciting experiences full of diverse outlooks anxiety, confusion, fear, and a desire to return home. For instance, in the Shipwrecked Sailor, the protagonist explores far from the Egyptian understandings of security and control. Thus, his voyage reveals the desire to understand the real reason behind his existence, a life of hindrances and strains, which eventually became habitual according to the Egyptian society, possibly even normal by being reincarnated into the next life.

Moreover, in the tale of Sinuhe, the hero searches for independence and knowledge, to an extent that his name means "son of sycamore". Perhaps it insinuates to his place of origin, or to a goddess "Lady of Sycamore" which was venerated in southern Memphis. ${ }^{47}$ Though when referring to goddess Hathor, it is a fact that she was the goddess of knowledge and thus, Sinuhe would become the son of knowledge, which he searched for beyond Egyptian territories and within foreign lands and cultures. ${ }^{48}$

Worth noting the ancient Egyptian sign for "geography" was not examined; such term meant "space", the town or city of accommodation of the protagonist, his origin and his aimed destination. The description of the place he visited, arouses a fictional contemporary knowledge of geography or locations. Analysis of these non-physical "geography" texts stimulate a wide range from royal to scribal texts, narrative to instructional and even official to private texts offering necessary social hierarchies. Opposites such as "city" and "country", "national" and "foreign", "close" and "far", are all correlated with a vastly distinct social life. In the tale of Sinuhe and the Eloquent peasant the determinatives km.t "town" and his.t "mountain" both present valuable verification on the cultural organization of geographic space.

Clearly there is a totally distinctive viewpoint between "Egypt" and "abroad"; it is represented within the context of the terms, "center', mostly recognized as "residence", written hnw, which also means "inside." Opposites are obvious in the use of the latter word. The literary characters of the Middle Kingdom stories constantly travel towards the center. Examples of the latter are in the Shipwrecked Sailor, Sinuhe's return home and even in the speech of the Eloquent peasant. Furthermore, in the story of the Shipwrecked Sailor, the protagonist passes Wawat and enters the Residence. As previously mentioned, an entirely different logical perception between the 
connection between "Egypt" and "abroad". 49

Most of the ancient Egyptian literary texts continue to be nameless, meaning that the characters were unnamed. It remains indistinct to us if the writer is the protagonist or he probably hopes to increase the significance of the instructions by designating the use of the "I" of a first person for a wise man. ${ }^{50}$ The latter was specifically common within wisdom texts or teaching instructions, such as in the tale of the Doomed prince. It was considered a short, timeless tale with repetitive sections, unnamed characters and talking animals. Noteworthy, the prince was in pursuit of his hidden true identity and destiny.

\section{Conclusion}

In the ancient Egyptian literary tales, it is crucial to compare several stories; definitely the stories of "The Shipwrecked Sailor, Sinuhe, The Doomed Prince, and Wenamun". The latter mentioned tales had endless analyses and articles either separately or collectively examine an initial theory connecting literary fiction and travels. It is remarkable that several of the travel tales combine more than one genre, such as Sinuhe, incorporates narrative, hymns, as well as, a letter. Whereas, a narrative frame in the form of a conversation is presented in the tale of the Eloquent Peasant.

Middle and New Kingdoms' travel literature were distinguished in a better form for the different genres of fiction, represented in their travels abroad to foreign lands. Although the major parts of fictional literature has the protagonist go past his boundaries, into dangerous infinite waters, waves, and tempests displayed distinctly in the stories of the Shipwrecked Sailor, Sinuhe, and Wenamun. An example of such mentioned in the Shipwrecked Sailor; as follows: "A tempest came when we were at (high) sea. Before we could reach land, the wind rose, it got stronger and there were waves eight cubits high. It was a beam that struck me. When the ship died, none was left that were on board". 51

Several literary travels fled to the Levant, such as Sinuhe, the Doomed prince, while Wenamun went as part of his mission, just like the Shipwrecked sailor; differently traveled south. There is a big possibility that both Sinuhe and the Shipwrecked sailor returned home successfully. Although, timeless eras and protagonists were used in the Shipwrecked sailor and the Doomed prince but yet all five stories were written in hieratic script. Realistic historical characters were reflected in the Tale of Sinuhe, the Eloquent peasant and in the report of Wenamun. Non- realistic or mythical characters were included in the Shipwrecked sailor and the Doomed prince. 
In ancient Egyptian travels geographical space altered according to the literary era. During the Old Kingdom personal travels of autobiographies expressed horizontal layout, such as Weni. Whilst differently of centripetal layout was the Middle Kingdom literary tales, which conveyed the protagonists' apprehensions and emotions, mostly away from any administrative orders. In Sinuhe and the Shipwrecked Sailor, travel is found in the form of a mission triggered by human weakness. Finally, an imaginary centrifugal layout was clear in the report of Wenamun. ${ }^{52} \mathrm{~A}$ voyage motivated by the search for the significance of life, for borders, for reasonableness and the protagonist's individuality.

${ }^{1}$ Lecturer of Tourism Guidance Faculty of Tourism \&Hotels-Suez Canal University

r H. Köpp-Junk, 2013, 'Travel', in E. Frood, W. Wendrich (ed.), UCLA Encyclopedia of Egyptology (L.A., 2013). 9,11.

T A.R. David, Handbook to Life in Ancient Egypt, (Oxford University Press, 1998). 259

4 G. Moers, Fingierte Welten in der ägyptischen Literatur des 2. Jahrtausends v. Chr.: Grenzüberschreitung, Reisemotiv und Fiktionalität (Leiden, 2001), 177, 220, 222, 232, 252 254, 282 ; J. Baines, "Interpreting Sinuhe". JEA 68 (1982). 39 - 42.

5C.E. Tureac, T. Anca, "Types and Forms of Tourism" in Economica Acta Universitatis Danubius Nr. 1(2008), 94, 95. 
6 H. Köpp, 2006, Reisen im alten Ägypten: Reisekultur, Fortbewegungs- und Transportmittel unter besonderer Berücksichtigung des Landverkehrs (Ph. D. diss. University of Göttingen, 2006), 1,2 ; J. Baines 'Travel in third and second millennium Egypt' in C. Adams, J. Roy (ed.) Travel, geography and culture in ancient Greece, Egypt and the Near East, Leicester Nottingham Studies in Ancient Society 10, (Oxford, 2007), 5,6. 7 H. Köpp 'Reisen in prädynastischer Zeit und Frühzeit' in E. Engel, V. Müller, U. Hartung (ed.) Zeichen aus dem Sand: Streiflichteraus Ägyptens Geschichtezu Ehren von Günter Dreyer, Menes 5, (Wiesbaden, 2008), 401 - 412; E. Eichler Untersuchungen zum Expeditionswesen des ägyptischen Alten Reiches. Göttinger Orientforschungen 26. (Wiesbaden, 1993), 269.

8 D. Darnell, J.C. Darnell 'Exploring the Narrow Doors of the Theban Desert' EA 10, (1997), $24-26$.

9 K. Zibelius-Chen, "Die ägyptische Expansionnach Nubien: Eine Darlegungder Grundfaktoren" Beiheft zum Tübinger Atlas des Vorderen Orients: Reihe B 78. (Wiesbaden, 1988), 144, 145.

10 E. Endesfelder, "Die Formierung der Klassengesellschaft: Probleme und Beobachtungen" in E. Endesfelder (ed.) Probleme der frühen Gesellschaftsent wicklung im Alten Ägypten, (Berlin, 1991), 17, 18.

11 E. Blumenthal, "Die Textgattung Expeditionsbericht in Ägypten" in J. Assmann, et al (eds.) Fragen an die altägyptische Literatur, (Wiesbaden, 1977), 87.

12 Tourism \& Hospitality studies. Manual on Module I. Introduction to Tourism. By Personal, Social and Humanities Education Section Education Bureau (2013), 48, 50.

13 L. Casson, Travel in the Ancient World (U.S.A, 1974), 21, 28, 31-33.

14 R. Soliman, "The Sacred Landscape of Ancient Thebes." Journal of the Faculty of Archaeology, Vol.5. (Qena, 2010), 26-28.

15 Köpp, Reisen im alten Ägypten, (2006), 7, 186, 193, 234, 243, 396, 397; R. Stadelmann, "Riding the donkey: A means of transportation for foreign rulers" in E. Czerny, et al (eds.) Timelines: Studies In honour of Manfred Bietak, Vol. II, OLA 149/2, (Leuven, 2006), 301.

16 L. Habachi, "The second stelae of Kamose and his struggle against the Hyksos ruler and his capital" DAIK 8 (Glückstadt, 1972), 36; A. Schulman, "Chariots, chariotry and the Hyksos" SSEA 10 (2), (1980), 146,148.

17 Köpp, Reisen im alten Ägypten, (2006), 217.

18 S. Vinson, "Egyptian boats and ships" Shire Egyptology 20 (UK, 1994), 11

19 I. Shaw, "Master of the Roads": Quarrying and communications networks in Egypt and Nubia" in B. Mathieu et al (eds.) L'apport de l'Égypte à l'histoire des techniques: Méthodes, chronologie et comparaisons. BdE 142, (2006), 258, fig. 6.

20 B. Kemp, Ancient Egypt. Anatomy of a civilization. (London, 1989), 281.

21 M. Verner, Zur Organisierung der Arbeitskräfte auf den Großbaustellen der Alten ReichsNekropolen. in E. Endesfelder (ed.) Probleme der frühen Gesellschaftsentwicklung im Alten Ägypten, (Berlin,1991), 65-66.

22 K. Sethe, Urkunden des Alten Reichs I (Leipzig, 1933).

23 K. Seyfried "Beiträge zu den Expeditionen des Mittleren Reiches in die Ostwüste" Hildesheimer ägyptologische Beiträge 15. (Hildesheim, 1981), 248 - 252; Kemp Ancient Egypt, 181.

24 L. Casson, Travel in the Ancient World, 21, 28, 29, 31-33. 
25 M. Verner, Zur Organisierung der Arbeitskräfte auf den Großbaustellen der Alten ReichsNekropolen. in E. Endesfelder (ed.) Probleme der frühen Gesellschaftsentwicklung im Alten Ägypten, (Berlin,1991), 77.

26 J. Baines, Die Bedeutung des Reisens im Alten Ägypten: 13. Siegfried-MorenzGedächtnis-Vorlesung 2002 (Leipzig, 2004), 43.

27 Köpp, Reisen im alten Ägypten, (2006), 5, 288, 309.

28 L. Casson, Travel in the Ancient World, 34.

29 R. Parkinson, The Tale of Sinuhe and other ancient Egyptian poems,1940-1640 BC. Sinuhe B 225 (Oxford, 1997), 38

30 E. Otto, "Die Geschichte des Sinuhe und des Schiffbrüchigen als "lehrhafte" Stücke", ZÄS 93, (1966), 103.

31 Papyrus Leningrad 1115, 120-123

32 J. Galán, Four journeys in ancient Egyptian literature. Lingua Aegyptia, Studia Monographica 5. (Papyrus Leningrad 1115), (Göttingen, 2005), 32, 68; R. Parkinson, (1997) The Tale of Sinuhe and other ancient Egyptian poems, 159-160.

33 L. Casson, Travel in the Ancient World, 39.

34 A. Loprieno, "Travel and fiction in Egyptian literature" in D. O'Connor \& S. Quirke (ed.) Mysterious lands, (London, 2003), 36.

35 Köpp, Reisen im alten Ägypten, (2006), 248, 301.

36 Sinuhe B11-14; translated by Galán, Four journeys in ancient Egyptian literature, 65.

37 Goedicke, JEA 43, 77-85.

38 Loprieno, "Toward a Geography of Egyptian Literature", 46, 47.

39 Papyrus Moscow 120 2, 50; translated by Galán, Four journeys in ancient Egyptian literature, 152,153 .

40 G. P. Gilbert, Ancient Egyptian Sea power and the origin of maritime forces. (Australia, 2008), 97.

41 A. Loprieno, "Toward a Geography of Egyptian Literature" in Cadmo 10 (Lisboa, $2000) 46$.

42 H. Goedicke, 'The route of Sinuhe's flight”, JEA 43 (1957), 77-85.

43 F. Taterka, "Hatshepsut and Senenmut or the Secret Affairs of the Egyptian State," in D. Lewandowska et al (eds.) Cupido Dominandi (2015).

44 Gilbert, Ancient Egyptian Sea power and the origin of maritime forces, 82, 108.

45A. Loprieno, "Toward a Geography of Egyptian Literature", 41.

46 Moers, Fingierte Welten in der ägyptischen Literatur, 247-251.

47A. M. Riad, A. A. Selim, N. S. Yanguas, "Conflict between Determinism, Individualism and Identity in Ancient Egyptian Thought" in: Journal of Religious Culture. Journal für Religionskultur. No. 202, (2015) 2-4.

48A. Loprieno, Defining Egyptian literature: Ancient texts and modern theories, in: A. Loprieno, (ed.); Probleme der Ägyptologie, Vol. 10, (Leiden, New York and Cologne, 1996), 44; Moers, Fingierte Welten in der ägyptischen Literatur , 91,92.

49 Loprieno, "Toward a Geography of Egyptian Literature", 44, 46, 48.

50 E. Bleiberg, Arts and Humanities Through the Eras in E. Bleiberg, (eds.) et al. Vol. 1. (Detroit, 2005), 121.

51 Papyrus Leningrad 1115 27-39; J. Galán, Four journeys in ancient Egyptian literature, 31. 52 Loprieno, "Toward a Geography of Egyptian Literature", 